\title{
EFFICACY AND SAFETY OF IVUS-GUIDED PERCUTANEOUS CORONARY INTERVENTIONS
}

Marija Popovic ${ }^{1}$, Mladen Tasic ${ }^{1}$ and Milena Grubisa ${ }^{2}$

Clinic for Cardiology, Clinical Center Kragujevac, Kragujevac, Serbia

${ }^{2}$ Center for Urgent Medicine, Clinical Center Kragujevac, Kragujevac, Serbia

\author{
EFIKASNOST I BEZBEDNOST IVUS VOĐENIH PERIUTANIH \\ KORONARNIH INTERVENCIJA \\ Marija Popović ${ }^{1}$, Mladen Tasić ${ }^{1}$ i Milena Grubiša ${ }^{2}$ \\ ${ }^{1}$ Klinika za kardiologiju, Klinički centar Kragujevac, Kragujevac, Srbija \\ ${ }^{2}$ Centar urgentnu medicinu, Klinički centar Kragujevac, Kragujevac, Srbija
}

\section{ABSTRACT}

The inclusion of IVUS-guided PCI has yet to become a routine approach in invasive cardiology due to the relatively high cost of the procedure, equivocal positive results in important studies and the steep learning curve. As an additional diagnostic tool, IVUS seems to be irreplaceable in stent apposition research, edge dissections and the determination of plaque composition.

To examine the efficacy and safety of IVUS-guided PCI vs. angiographically guided PCI in a centre without prior experience.

A total of 35 patients were examined using IVUS prior to stent placement, and the gathered data were used to determine adequate implanted stent size and length. The acquired parameters were as follows: percentage of stenosis, MLD, CSA and distal reference diameter. After PCI, IVUS studies were repeated and data on the CSA, residual stenosis and MLD were acquired. Additionally, stent size and length, deployment pressure and the use of additional post-dilatations were recorded. There were 35 patients with similar demographic data in the control group who underwent treatment of the same vessel segment with the same stent type. Additional data regarding acute complications (dissections, slow flow during or after the procedure, IM) were obtained from the existing database and complications after six months, such as the need for TVR, MACE and death, were also obtained.

Significant differences were observed in terms of stent size and length, residual stenosis, post-dilatation and MLD in favour of the IVUS group; in addition, TVR was 36\% lower in the IVUS group with no significant difference in MACE and death between the groups.

After introduction of the method, IVUS-guided PCI exhibited reasonable safety and efficacy compared to conventional angiographically guided $P C I$ at centres without prior experience.

\section{SAŽETAK}

Uvođenje IVUS vođenih PCI još uvek ne predstavlja rutinsku metodu u invazivnoj kardiologiji zbog relativno visoke cene procedure, dvosmislenih pozitivnih rezultata u važnim studijama i visokoj krivi učenja. Kao pomoćno dijagnostičko sredstvo IVUS se pokazao nezamenjivim u ispitivanju apozicije stenta, pojavi ivičnih disekcija kao i u ispitivanju sastava plaka.

Ispitati efikasnost $i$ bezbednost IVUS vodenih PCI naspram angiografski vodenih PCI u centru bez prethodnog iskustva.

Ukupno 35 pacijenata je ispitivano IVUS pre postavljanja stenta, i dobijeni podaci su korišćeni pri odabiru veličine $i$ dužine implantiranog stenta. Korišćeni podaci su bili procenat stenoze, $M L D$, površina preseka krvnog suda (CSA) i distalni referentni dijametar. Nakon PCI, IVUS ispitivanja su ponovljena i dobijeni su podaci o CSA, rezidualnoj stenozi i MLD. Takode, notirani su veličina i $d u-$ žina stenta, raspoređivanje pritiska $i$ korišćenje dodatnih post-dilatacija. U kontrolnoj grupi je bilo 35 pacijenata sličnih demografskih podataka, tretirani istim koronarnim segmentom $i$ korišćenim istim tipom stenta. Dodatni podaci o akutnim komplikacijama (disekcija, spor protok tokom i posle procedure, IM) su dobijeni iz postojeće baze podataka i posle šest meseci poput potrebe za TVR, MACE i smrtni ishod.

Uočena je statstički značajna razlika u veličini i dužini stenta, rezidualnoj stenozi, post-dilataciji i MLD u korist IVUS grupe, takode TVR je bio 36\% niži u IVUS grupi sa beznačajnim razlikama u MACE $i$ smrtnom ishodu.

Po uvodenju metode, IVUS vodene PCI su se pokazale sigurnim $i$ efikasnim u odnosu na konvencionalne angiografski vođene PCI u centru bez ranijeg iskustva. 


\section{ABBREVIATIONS}

IVUS - intravascular ultrasound

PCI - percutaneous coronary intervention

MLD - minimal lumen diameter
CSA - cross sectional area

TVR - target vessel revascularization

MACE - major cardiac adverse event

\section{INTRODUCTION}

Intravascular ultrasound (IVUS) is based on applying high frequency ultrasound for the detection and visualization of intracoronary structures and for localization and for determining the size and significance of intravascular atherosclerosis plaques. Different structure detection methods are based on different echogenic characteristics of the vessel parts. Due to excellent image quality and spatial resolution, IVUS represents the complementary method of choice for ordinary angiographic diagnostic approaches during the examination of lumen size and vessel size, plaque load and plaque composition as well as remodelling of the artery. IVUS enables the identification of lesions for which revascularization does not need to be performed. The treatment procedure during PCI can include IVUS, and an appropriately placed stent can be assessed (1).

The major limitation of coronary angiography is that the anatomy cannot be strictly defined due to the two-dimensional projections of a three-dimensional coronary lumen. Additionally, diffuse disease distant from the lesion, lesion abbreviation, angulations, calcifications, plaque eccentricity, vessel overlap, and turbulent contrast may complicate the determination of the lesion size. More accurate lumen and vessel dimensions are obtained using IVUS, so as reproduced data.

Intermediary lesions are still a therapeutic dilemma in interventional cardiology, and there is significant inconsistency in defining the significance of these lesions between different operators and after repeat evaluations by the same operators (2). IVUS is a well-established method in interventional cardiology, and its introduction led to significant advances in the efficacy, procedure technique and adjunct medication protocols with PCI $(3,4,5)$. IVUS contributed to a better understanding of the possibilities and limitations of angiographic examination $(6,7)$.

Currently, the question is whether the routine use of IVUS is medically and financially effective. The use of high pressure during stent implementation directly derived from IVUS studies significantly reduced the need for repeat interventions, and it was proved to be a safe and efficient method. Previous studies proved that angiographically guided procedures are not inferior to IVUS-guided procedures regarding repeat revascularization, myocardium infarcts and mortality, although MLD and the residual stenosis percentage were better with IVUS-guided procedures $(8,9,10)$.

\section{MATERIALS AND METHODS.}

Both observational and retrospective research were performed. A total of 70 patients were tested in the two groups. In one tested group, 35 patients underwent diagnostic IVUS with elective PCI. Angiographic data gathered before the IVUS procedure were used to classify the lesions according to weight (11), stenosis level, minimal stenosis diameter and DRD vessel size (DRD). Patients with three-vessel disease and disease of the left main coronary artery were not included in this study. The monitored data included stenosis percentage, MLD, cross section area (CSA), and size of the distal reference diameter. After stent implementation, IVUS was repeated and the CSA as well as the residual stenosis percentage and MLD were measured. The size of the stent, implanted pressure, the use of the NC balloon (size and post-dilatation pressure) were entered into the database (register). The patients in the control group underwent treatment of the same segment and implantation with the same stent type; in addition, values derived from the angiographic examination of MLD, stenosis percentage, and the size of the distal reference diameter measured by QCA. Data on the type, size and length of the stent, NC balloon use (with size and pressure of the balloon inflation) were also obtained from the database. Data on dissection and spasm were also obtained from the patient database.

The patients were questioned by telephone or the database was accessed for the following reasons: there were repeat revascularizations on an implanted stent over 6 months (TVR - target vessel revascularisation); composite MACE (major adverse cardiac event) with bleeding that required treatment; acute complications during PCI, including spasm lasting more than 5 minutes, vessel dissection and permanent lateral branch block; and acute coronary changes (defined by an increase of $\mathrm{TnI}>0.16$ and EKG changes, death outcome related to cardiac function occurring between a month and six months after the intervention).

Data were collected retrospectively and measurements were performed by an independent examiner using producer equipment software: QCA - Siemens Medical and iLAB - Boston Scientific. All procedures were performed by two operators who did not have significant prior experience with diagnostic IVUS.

There were no differences between the two groups regarding the mean age, percentage of diabetes, percentage 
of DES or lesion type in the vessels. The vessel size defined by IVUS was $15 \%$ larger than the angiographically estimated size, and there were differences in the measurements between the two methods within the IVUS group (3, $35 \pm 0$, 5 vs. 2, 95 $\pm 0,7$ measured by QCA, $<<0,05$ ); in addition, during angiographic estimation of the vessel size, significant differences were not observed $(2,95 \pm 0,7$ vs. $2,89 \pm 0$, $6, \mathrm{p}=0,11)$. The TVR number was smaller than in the IVUS group, and there were more patients who underwent PCI in the IVUS group. NC balloon use was two-fold higher in the IVUS tested group.

Statistical data were processed using the IBM Statistics - SPSS 19 program package; the T-test was used for independent samples for values with a normal distribution, whereas for other values, the Mann-Whitney test was used.

Due to the small number of patients, MACE varied from case to case and occurred in patients with many restenosis episodes and on implanted DES (death outcome with 24 hours due to thrombosis on POBA with cutting balloon) in the IVUS group as well as dissection distal to the implanted stent; in the control group, the lateral branch was blocked and dissection and acute bleeding at the puncture location occurred (3 patients in both cases).

\section{RESULTS.}

Table $(1,2,3)$

The following observations were based on the results:

1. Differences in the estimation of vessel size between groups, such as lesion length (figures 1, 2, and 3)

2. Considerably greater use of NC balloons for post-dilatation of implanted stents, which can be explained by the advanced quality of IVUS, which can be used to assess inadequate stent expansion, as well as the inflation intensity due to operator knowledge of the actual size of the vessel (figures 4,5)

3. Reduced need for repeat revascularization after IVUS-guided procedures with a similar complication percentage for both procedures.

\section{DISCUSSION}

The results of significant studies indicate that an experienced operator is required for routine guided procedures for the interpretation of the data gathered with IVUS; these results were found in a few studies that involved the use of IVUS at a small centre and without significant prior experience. Earlier data do not support the routine use of IVUS $(8,9,10,11,12)$, although we obtained results in favour of a decrease in TVR without a significant difference. Documentary data indicate that the differences are related to acquisition in cases involving small and long lesions, such as lesions on venous grafts for which appropriate angiographically obtained data on the lesion type and length
Table 1. Patients characteristics and coronary lesion

\begin{tabular}{|c|c|c|c|}
\hline Mean age & 60,3 & 61 & NS \\
\hline Diabetes & 23 & 24 & NS \\
\hline DES (\%) & $21 \%$ & $23 \%$ & NS \\
\hline$\%$ of treated vessels & IVUS & Control & $\mathbf{P}$ \\
\hline One & $75 \%$ & $67 \%$ & NS \\
\hline Two & $25 \%$ & $33 \%$ & NS \\
\hline Previous PCI & $15 \%$ & $12 \%$ & NS \\
\hline Previous CABG & $0 \%$ & $0 \%$ & / \\
\hline Blood vessel \% & IVUS & Control & $\mathbf{P}$ \\
\hline LAD & 45 & 46 & NS \\
\hline $\mathrm{LCx}$ & 25 & 36 & NS \\
\hline $\mathrm{RCA}$ & 33 & 18 & NS \\
\hline Lesion type \% & IVUS & Control & $\mathbf{P}$ \\
\hline Type A & 15 & 13 & $\mathrm{NS}$ \\
\hline Type B1 & 25 & 22 & NS \\
\hline Type B2 & 52 & 60 & NS \\
\hline Type C & 8 & 5 & $\mathrm{NS}$ \\
\hline 1 vessel & 77 & 68,5 & NS \\
\hline 2 vessel & 23 & 31,5 & NS \\
\hline Previous PCI & 17 & 11,5 & NS \\
\hline
\end{tabular}

Table 2. Parameters of procedure

\begin{tabular}{|l|l|l|l|}
\hline Measurement & IVUS & Control & $\mathbf{P}$ \\
\hline MLD & $1,1 \pm 0,04$ & $1,3 \pm 0,2$ & $\mathrm{NS}$ \\
\hline MLD (post) & $3,5 \pm 0,5$ & $\begin{array}{l}3,1 \pm 0,4 \\
(\mathrm{Q} C A)\end{array}$ & $\mathrm{P}=0,002$ \\
\hline $\begin{array}{l}\text { Distal reference } \\
\text { diameter }\end{array}$ & $3,38 \pm 0,5$ & 2,89 & $\mathrm{P}=0,042$ \\
\hline Stent length & $18,5 \pm 2,2$ & $16,9 \pm 1,7$ & $\mathrm{P}=0,002$ \\
\hline Inflation pressure & $15,5 \pm 1,9$ & $13,9 \pm 1,8$ & $\mathrm{P}=0,001$ \\
\hline Stent size & $3,44 \pm 0,6$ & $3,03 \pm 0,5$ & $\mathrm{P}=0,004$ \\
\hline postdilatation $\mathbf{\%})$ & 45,7 & 22,9 & $\mathrm{P}<0,0001$ \\
\hline Residual stenosis \% & $5,7 \%$ & $14,28 \%$ & $\mathrm{P}=0,23$ \\
\hline $\begin{array}{l}\text { Postdilatation } \\
\text { pressure }\end{array}$ & $22,7 \pm 2,2$ & $20,3 \pm 1,9$ & $\mathrm{P}<0,001$ \\
\hline
\end{tabular}

Table 3. Coronary events

\begin{tabular}{|l|l|l|l|}
\hline Clinical data & IVUS & Control & $\mathbf{P}$ \\
\hline TVR (\%) & $6,7 \%$ & $10,6 \%$ & $\mathrm{P}=0,039$ \\
\hline MACE & $5,7 \%$ & $5,7 \%$ & $\mathrm{NS}$ \\
\hline Death & $/$ & $/$ & $\mathrm{NS}$ \\
\hline Slow/no reflow & $/$ & $2,8 \%$ & $\mathrm{NS}$ \\
\hline Dissection & $2,8 \%$ & $/$ & $\mathrm{NS}$ \\
\hline
\end{tabular}




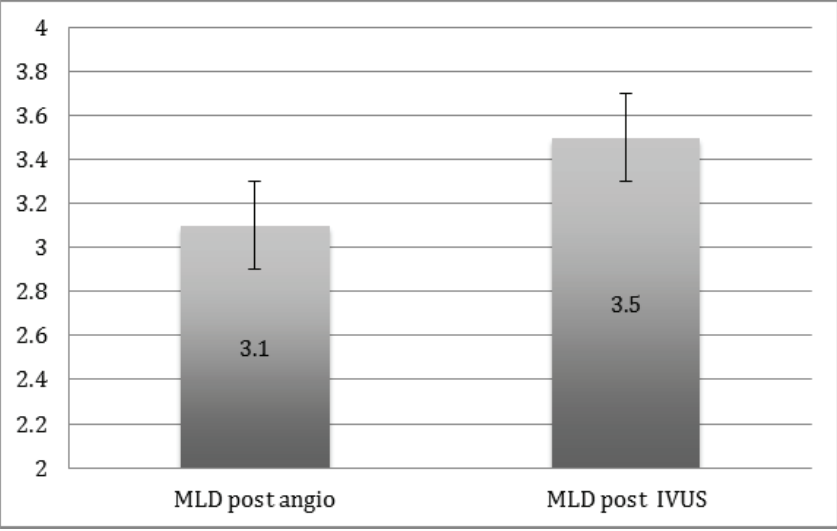

Figure 1. MLD post

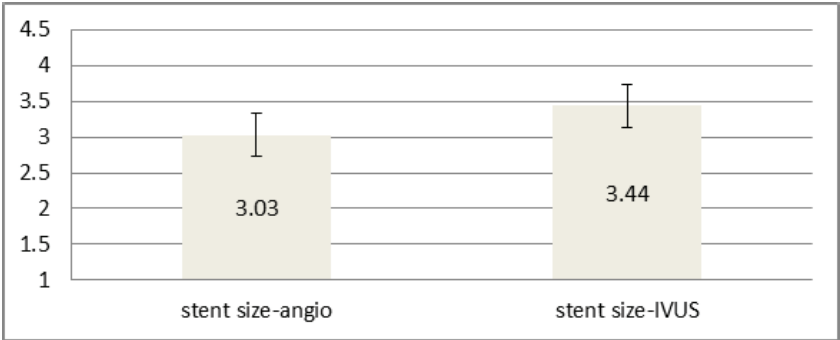

Figure 2. Stent lenght

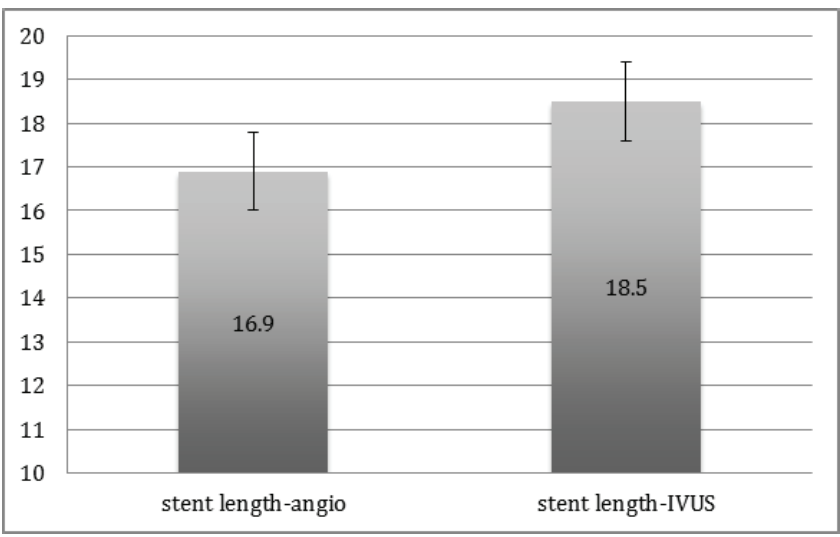

Figure 3. Stent lenght

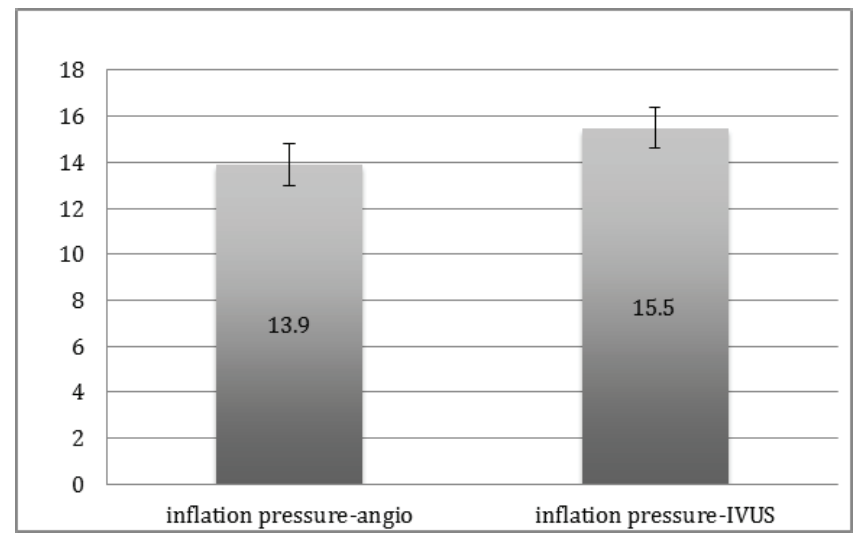

Figure 4. Inflation pressure cannot be obtained; these lesions are often treated using inadequate stents (which are smaller but not sufficiently long), resulting in the need for additional treatment or repeat interventions. Negative results indicate that stent premeasurements and vessel injury, such as shear stress decreases, can additionally accelerate the restenosis process as shown in porcine models (13). Based on a significant increase in DES use in clinical practice, the dependency of stent strut apposition to the vessel is noted and decreases the acute complications of percutaneous interventions (14); in addition, low lumen size estimates, existing diseased segments proximally and distally from the placed stents and existing but unobservable angiographic dissections are predictors of early PCI complications (15). On the other hand, IVUS did not show a significant influence on stent restenosis in patients treated with DES (15).

IVUS remains a useful instrument for LM interventions, and many studies have demonstrated the benefit from the precise determination of stent size and post-implant results $(16,17,18,19)$. Our cumulative data without determining the subgroups regarding stent size and type do not prove that routine IVUS produces better overall results regarding composite MACE but significantly decreased the need for additional interventions. Data also proved that IVUS-guided procedures can be performed at centres without significant IVUS experience. Further research and more IVUS-guided procedures would indicate whether this PCI method has clinical benefits at small-to-medium-sized centres. We emphasize the need for IVUS-guided interventions at centres without cardiosurgical support where acute complications can significantly endanger the clinical status of patients and the procedure effects. Furthermore, because of the emerging trend of introducing early treatment of acute coronary syndrome by percutaneous interventions that are accompanied by a significantly higher early and late mortality and morbidity than that of elective PCI, the need arises to re-examine the origin of unstable plaques and therapeutic treatment options (17).

Conclusions. After introduction of the method, IVUSguided PCI proved to be of reasonable safety and efficacy compared to conventional angiographic guided PCI at centres without prior experience.

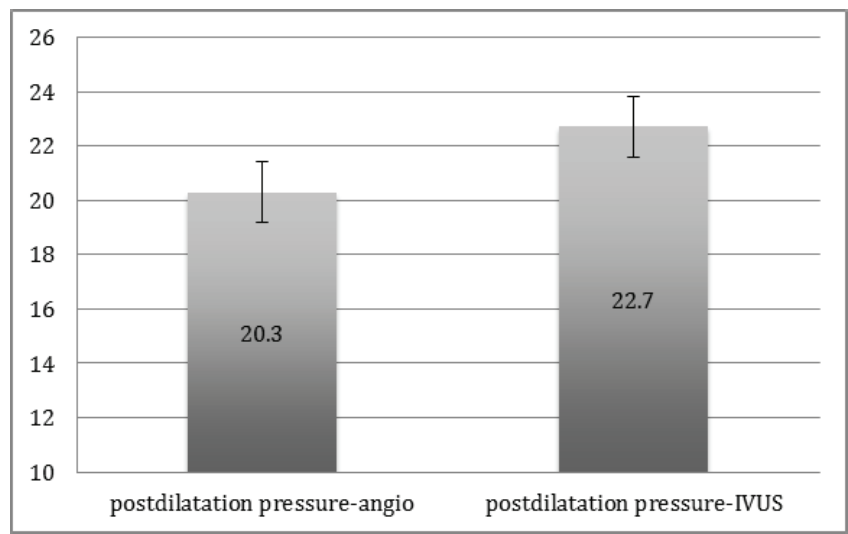

Figure 5. Postdilatation pressure 


\section{REFERENCES}

1. Mintz GS, Nissen SE, Anderson WD, Bailey SR, Erbel R, Fitzgerald PJ, Pinto FJ, Rosenfield K, Siegel RJ, Tuzcu EM and Yock PG. ACC Clinical Expert Consensus Document on Standards for the acquisition, measurement and reporting of intravascular ultrasound studies: a report of the American College of Cardiology Task Force on Clinical Expert Consensus Documents (Committee to Develop a Clinical Expert Consensus Document on Standards for Acquisition, Measurement and Reporting of Intravascular Ultrasound Studies [IVUS]). J Am Coll Cardiol 2001;37:1478-1492.

2. Fischer JJ, Samady H, McPherson JA et al. Comparison between visual assessment and quantitative angiography versus fractional flow reserve for native coronary narrowings of moderate severity. Am J Cardiol 2002 ;90: 210-215.

3. Serruys PW, Jaegere P, Kiemeneij F et al. A comparison of balloon-expandable-stent implantation with balloon angioplasty in patients with coronary artery disease. $\mathrm{N}$ Engl J Med 1994;331: 489-495.

4. Colombo A, Hall P, Nakamura $S$ et al. Intracoronary stenting without anticoagulation accomplished with intravascular ultrasound guidance. Circulation 1995;91:676-1688.

5. Goods CM, Al-Shaibi KF, Yadav SS et al. Utilization of the coronary balloon-expandable coil stent without anticoagulation or intravascular ultrasound. Circulation 1996; 93:1803-1808.

6. Laskey WK, Brady ST, Kussmaul WG et al. Intravascular ultrasonographic assessment of the results of coronary artery stenting. Am Heart J 1993;125:1235-1240.

7. Topol EJ and Nissen . Our preoccupation with coronary luminology: The dissociation between clinical and angiographic findings in ischemic heart disease. Circulation 1995;92: 2333-2342.

8. Fitzgerald PJ, Oshima A, Hayase M et al. Final results of the Can Routine Ultrasound Influence Stent Expansion (CRUISE) study. Circulation 2000;102:523-530.

9. Jaegere de P, Mudra H, Figulla $\mathrm{H}$ et al. Intravascular ultrasound-guided optimized stent deployment: Immediate and 6-months clinical and angiographic results from the Multicenter Ultrasound Stenting In Coronaries (music) study. Eur Heart J 1998; 19 :1214-1223.
10. Albiero R, Rau T, Schluter M et al. Comparison of immediate and intermediate-term results of intravascular ultrasound versus angiography-guided Palmaz-Schatz stent implantation in matched lesions. Circulation 1997; 96 : 2997-3005.

11. Ellis SG, Vandormael MG, Cowley MJ, and the POSCH Group. Coronary morphologic and clinical determinates of procedural outcome with angioplasty for multivessel coronary disease: implications for patient selection. Circulation 1990;82:1193-1202.

12. Fitzgerald PJ, Oshim A, Hayase $M$ et al. Final results of the Can Routine Ultrasound Influence Stent Expansion (CRUISE) study. Circulation 2000;102:523-530.

13. Schwarz RS, Huber $\mathrm{KC}$ et al. Restenosis and the prportional neointimal response to coronary injury: results in porcine model. J Am Coll Cardiol 1992;19:267-274.

14. F Schiele, N Meneveau, A Vuillemenot et al. Impact of intravascular ultrasound guidance in stent deployment on 6-month restenosis rate: A multicenter, randomized study comparing two strategies-with and without intravascular ultrasound guidance. J Am Coll Cardiol 1998;32:320-328.

15. Eshtehardi P, Cook S, Wandel $S$ et al. Impact of incomplete stent apposition on long-term clinical outcome after drug-eluting stent implantation: an intravascular ultrasound study. Eur Heart J 29 2008; 29:338.

16. Park SM, Kim JS, Ko YG et al. Angiographic and intravascular ultrasound follow up of paclitaxel- and sirolimus-eluting stent after poststent high-pressure balloon dilation: from the poststent optimal stent expansion trial. Catheter Cardiovasc Interv 2011;77:15-21.

17. Choi SY, Witzenbichler B, Maehara A et al. Intravascular ultrasound findings of early stent thrombosis after primary percutaneous intervention in acute myocardial infarction: a Harmonizing Outcomes with Revascularization and Stents in Acute Myocardial Infarction (HORIZONS-AMI) substudy. Circ Cardiovasc Interv 2011;4: 239-247.

18. Park SJ, Kim YH, Park DW et al. Impact of intravascular ultrasound guidance on long-term mortality in stenting for unprotected left main coronary artery stenosis. Circ Cardiovasc Interv 2009;2: 167-177.

19. Park SJ, Kim YH, Park DW et al. Impact of intravascular ultrasound guidance on long-term mortality in stenting for unprotected left main coronary artery stenosis. Circ Cardiovasc Interv 2009;2: 167-17. 